Portland State University

PDXScholar

University Honors Theses

University Honors College

5-24-2019

\title{
University Honors Media Archive
}

Noah B. Puggarana

Portland State University

Follow this and additional works at: https://pdxscholar.library.pdx.edu/honorstheses

Let us know how access to this document benefits you.

\section{Recommended Citation}

Puggarana, Noah B., "University Honors Media Archive" (2019). University Honors Theses. Paper 853.

https://doi.org/10.15760/honors.874

This Thesis is brought to you for free and open access. It has been accepted for inclusion in University Honors Theses by an authorized administrator of PDXScholar. Please contact us if we can make this document more accessible: pdxscholar@pdx.edu. 


\section{Welcome to \\ University \\ Honors}

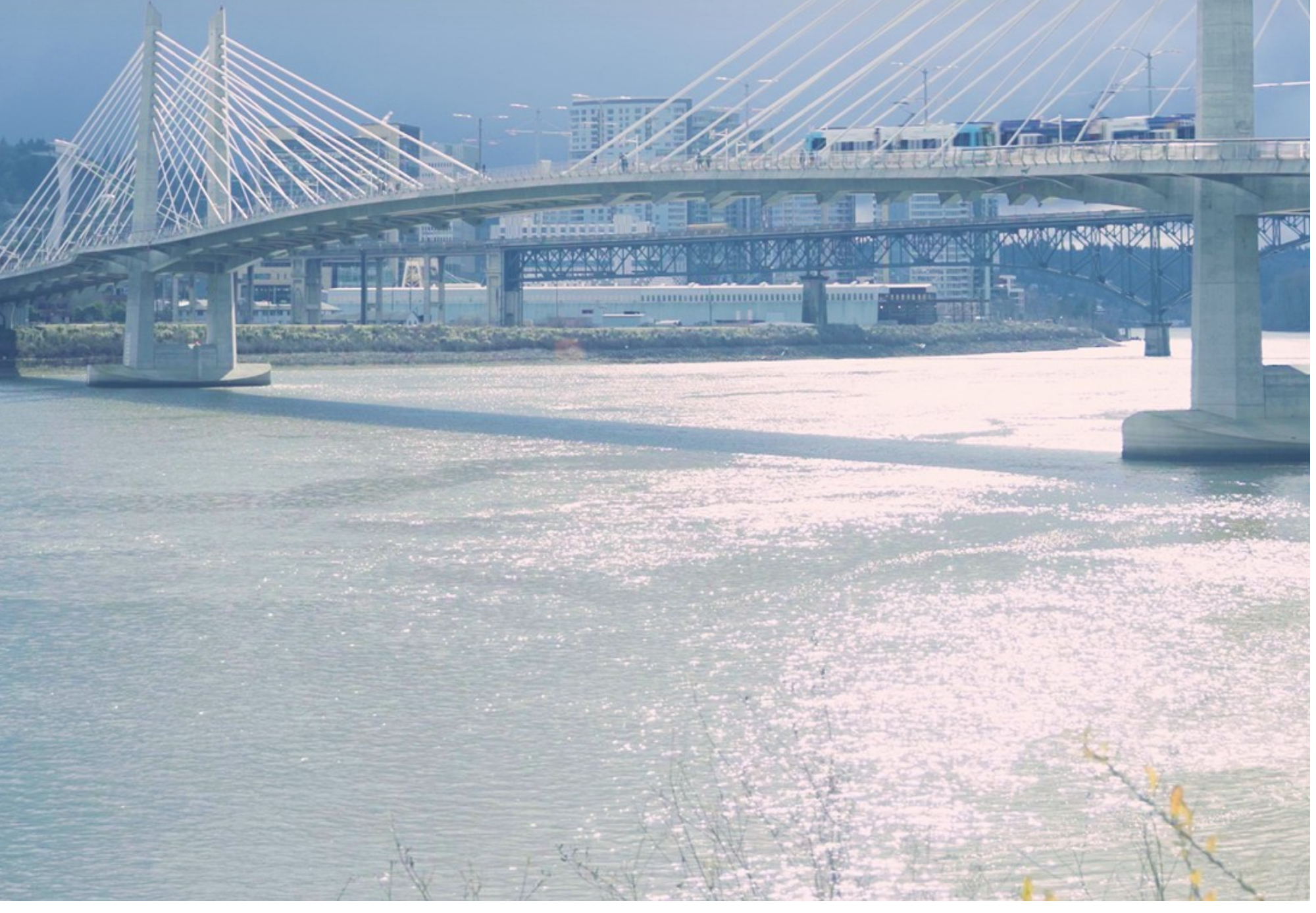




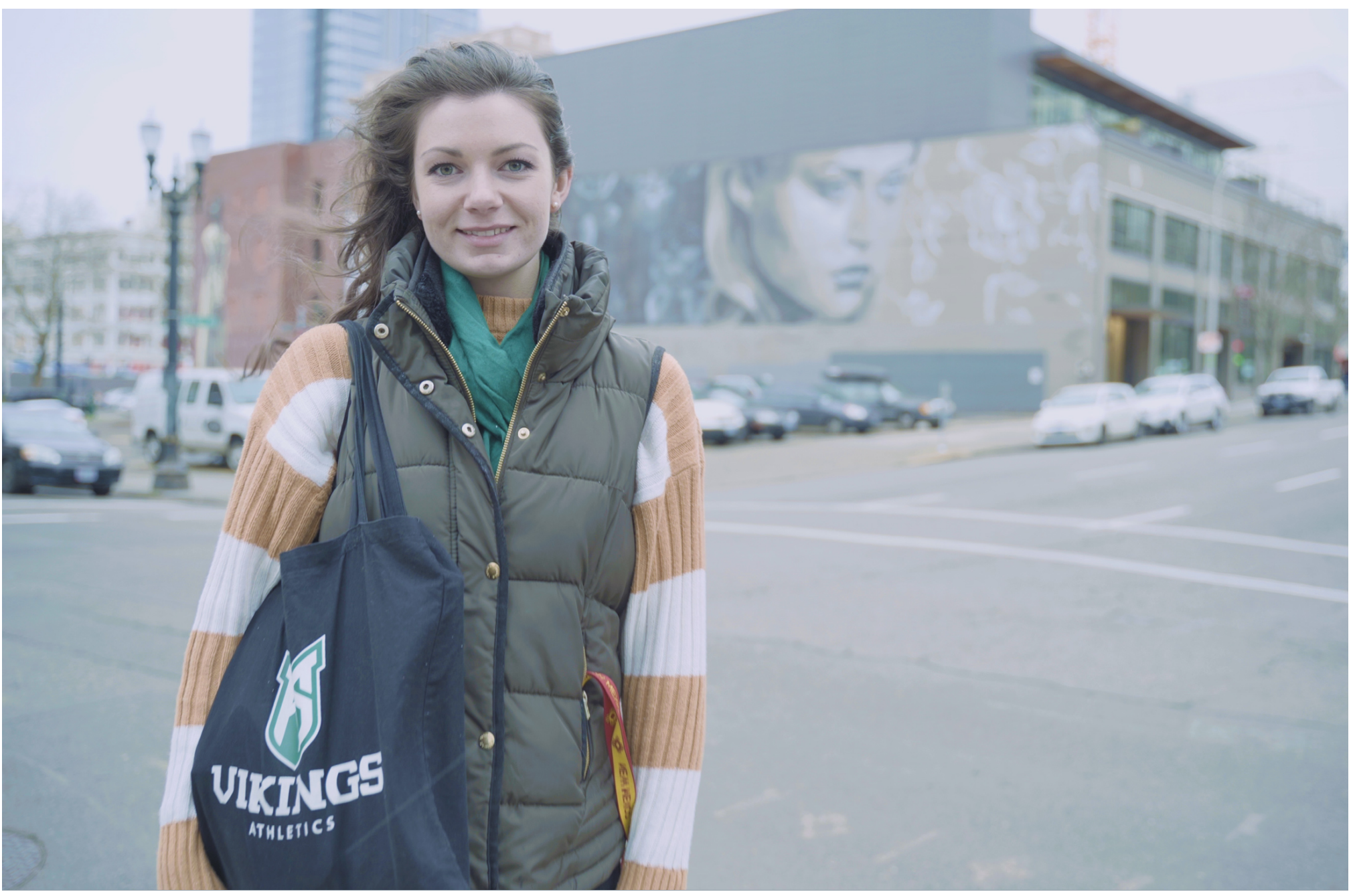

Meet a group of Honors students that use their education to interact with the city of Portland. Portland State University Honors focuses on providing a focused academic community for students of all backgrounds.

"Welcome to University Honors" is a branded video made in cooperation with University Honors and the PSU School of Film as part of the undergraduate Honors Thesis. 


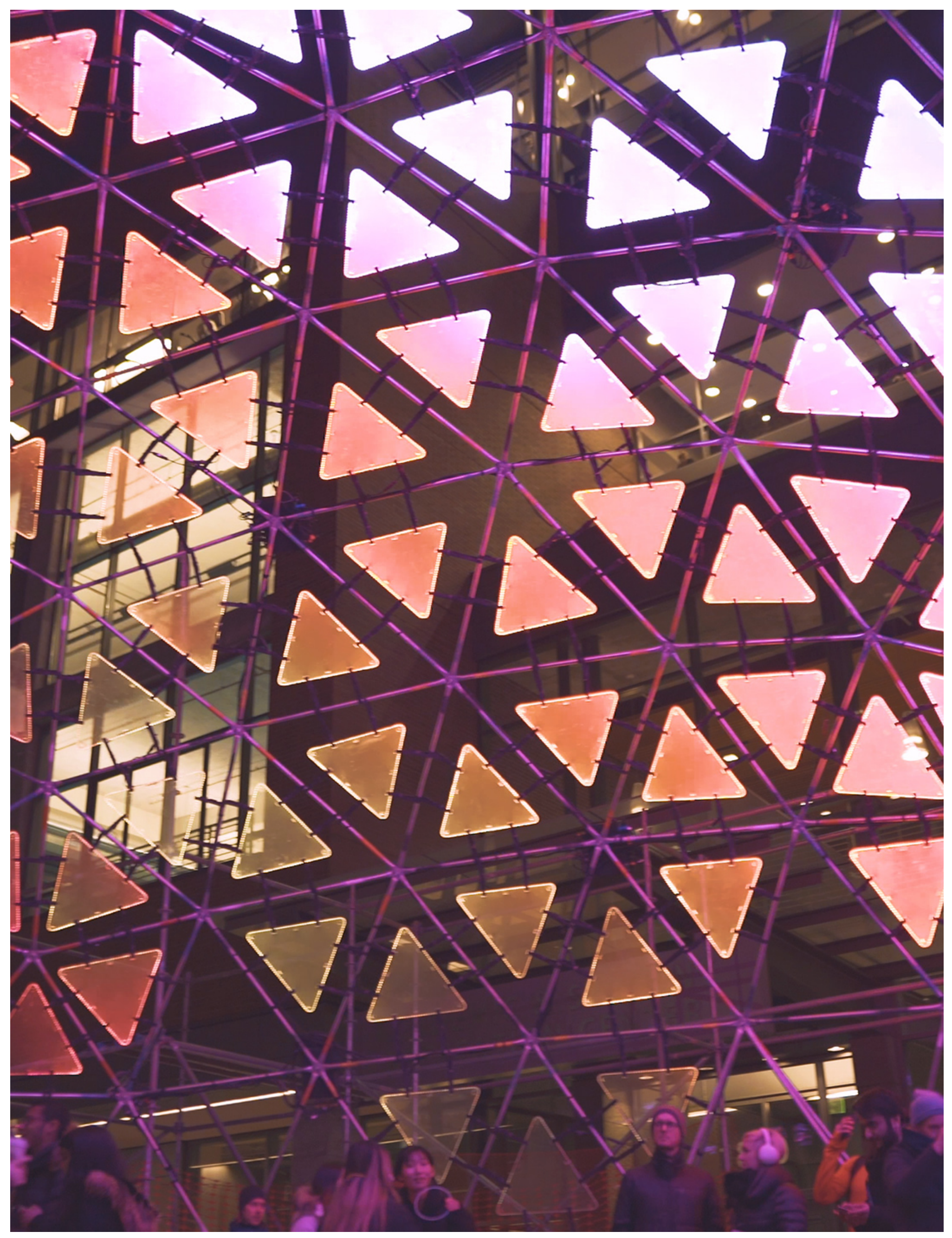




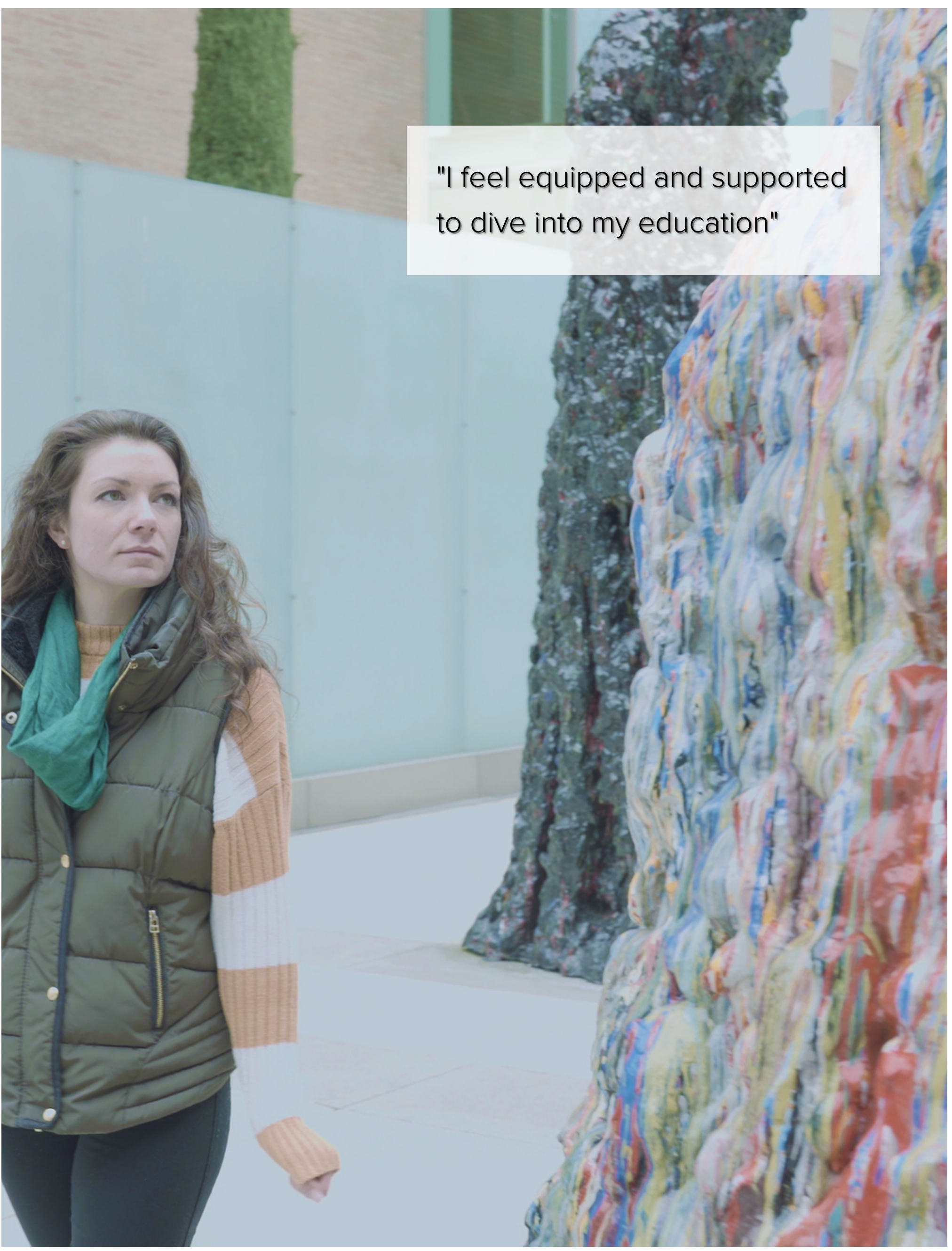




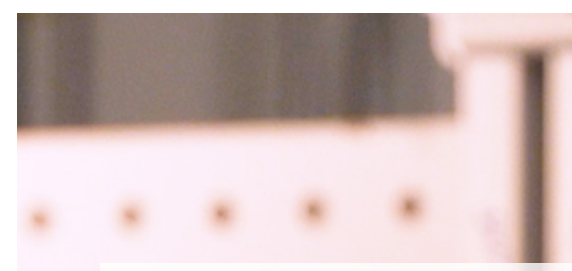

"I got the resources to point me in the right direction"

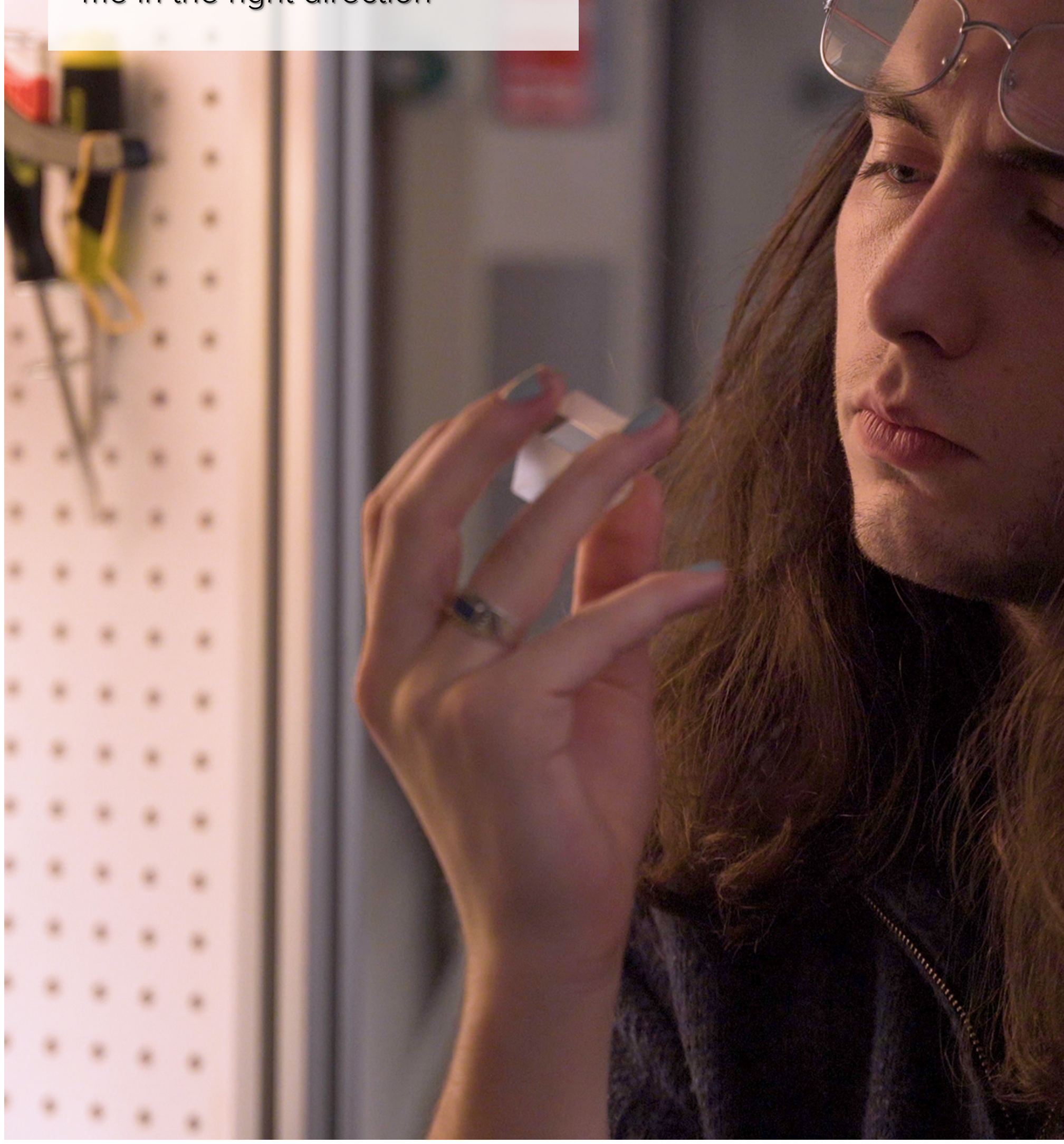




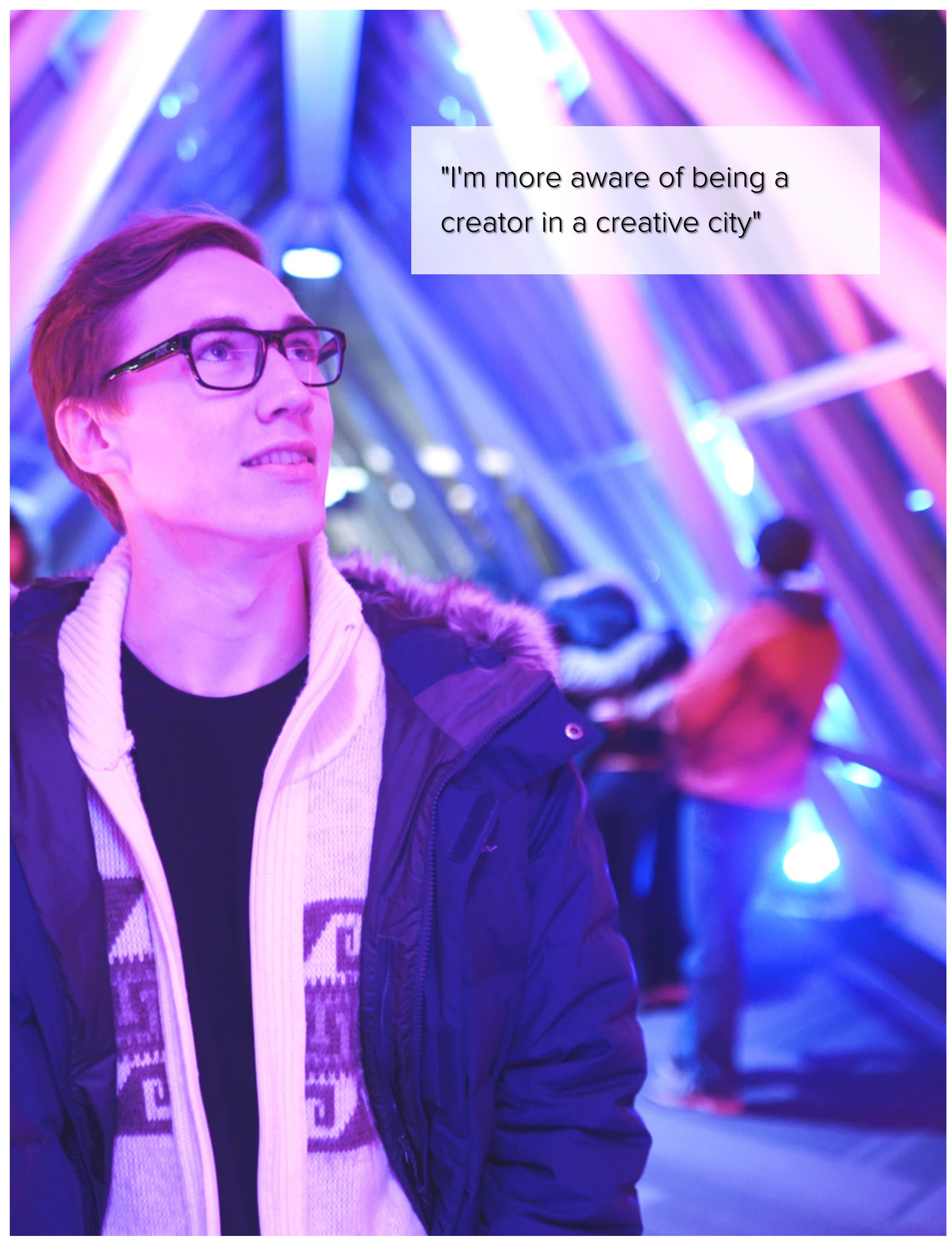




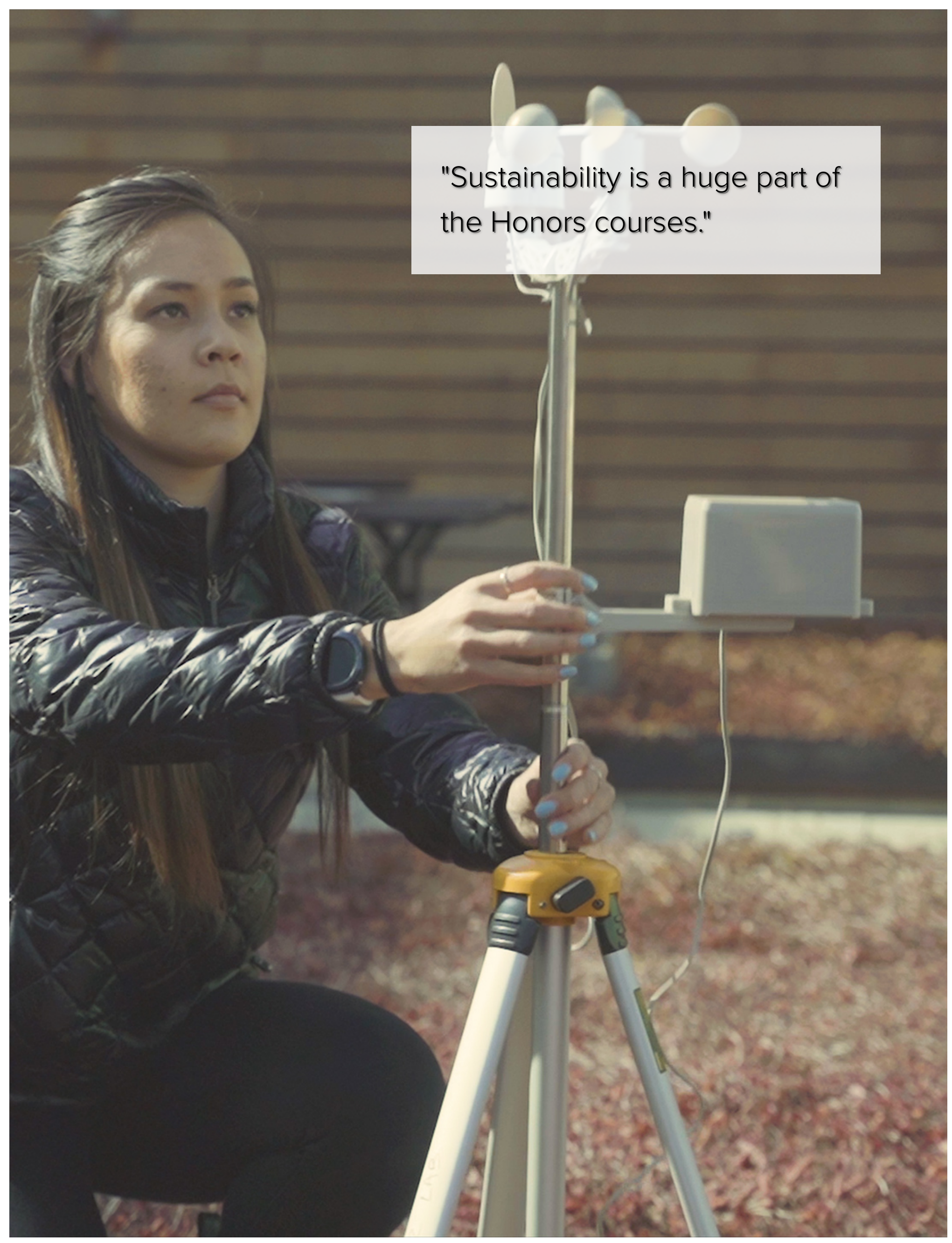



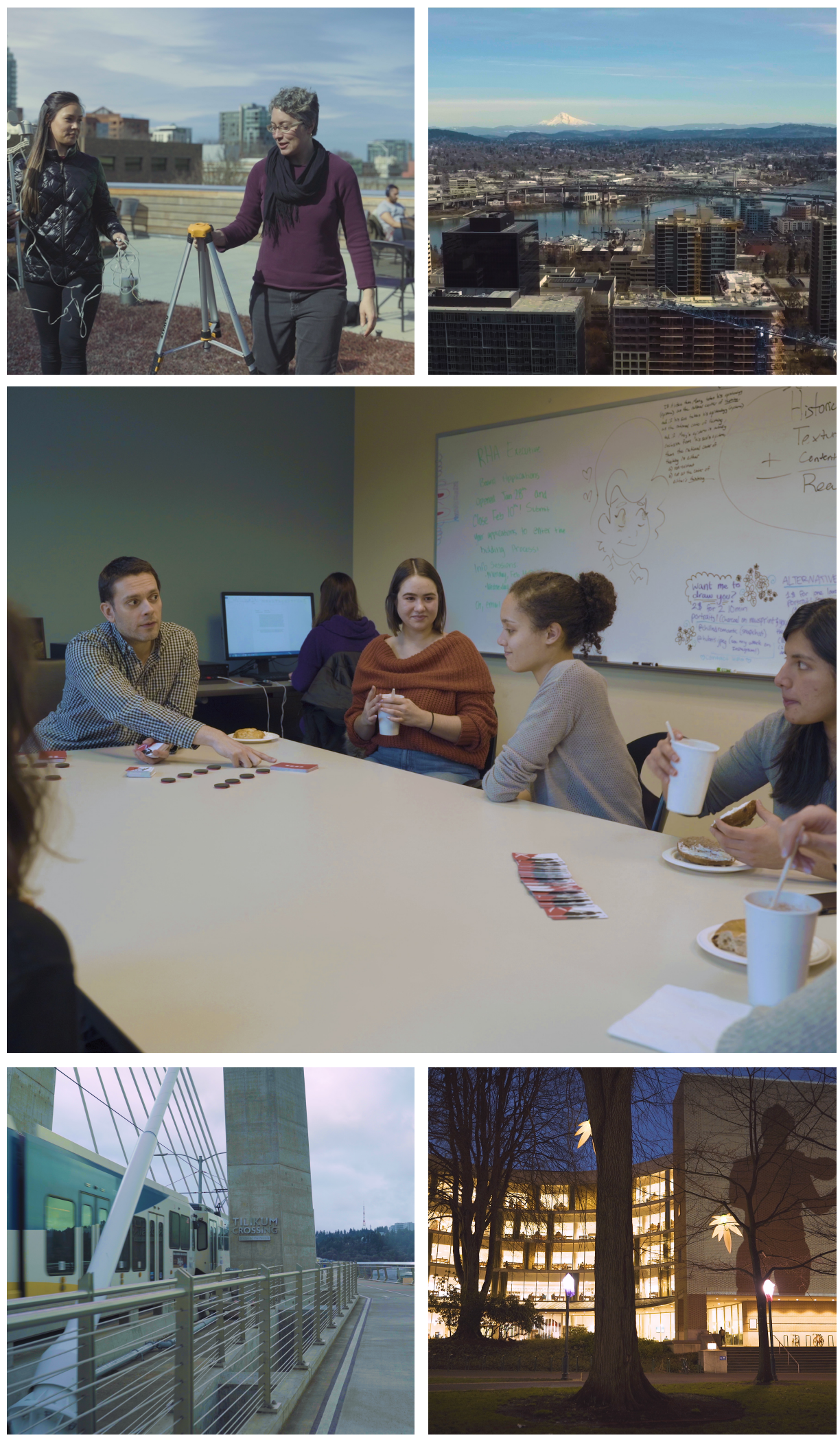


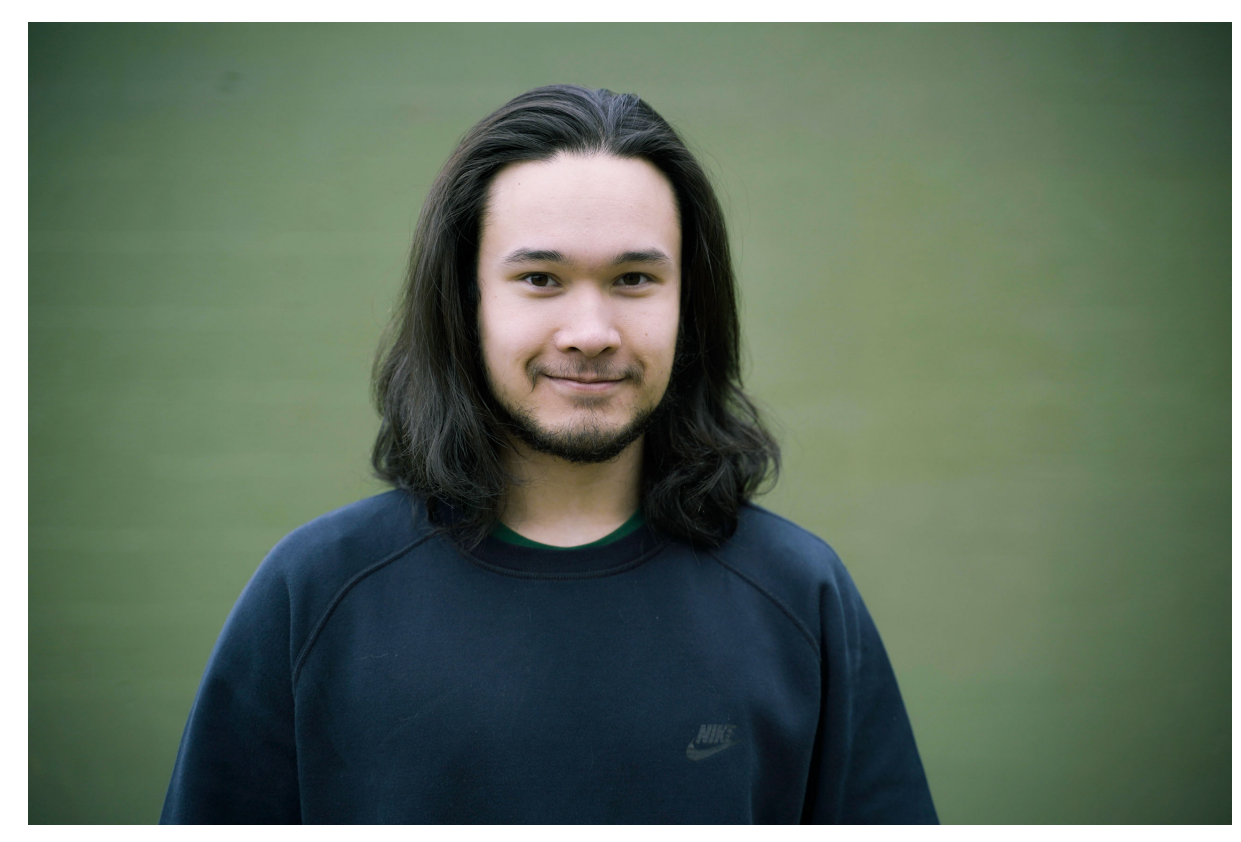

\title{
Noah Puggarana
}

\section{Director}

\author{
Based in Portland, Oregon, USA
}

I am an independent audio/visual producer who focuses on people interacting with the city. My goal is to capture stories that inspire, entertain, and educate people to change the world. 


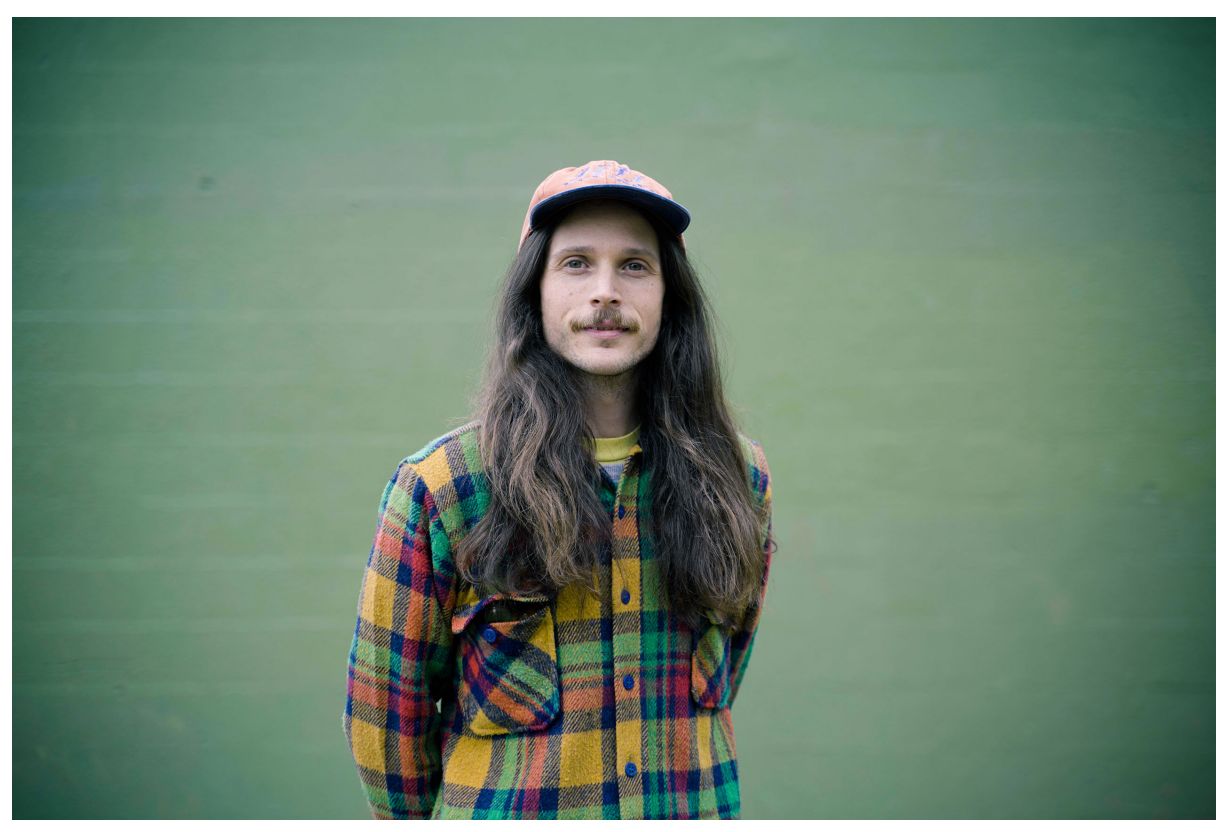

\section{Brian Jackson}

\section{Sound Recorder}

Brian is a filmmaker and musician from Sacramento, California. He studies film at Portland State University. He is currently working as a producer with Lake Productions. 


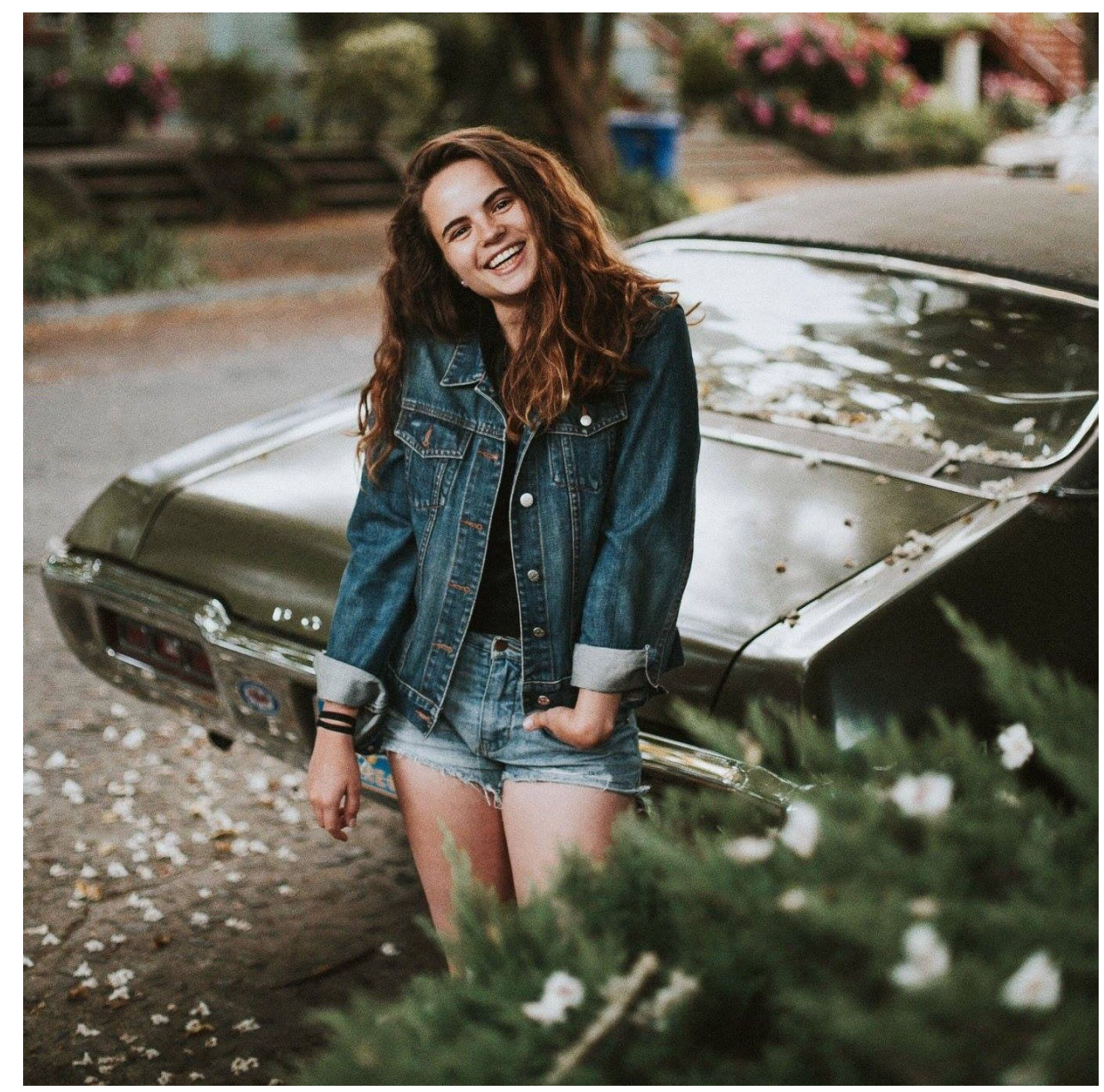

\section{Emma Josephson}

\section{Assistant Camera}

Emma is a filmmaker from Vancouver, WA. She is a Portland State University student. She is currently working as a director with PSU.tv. 


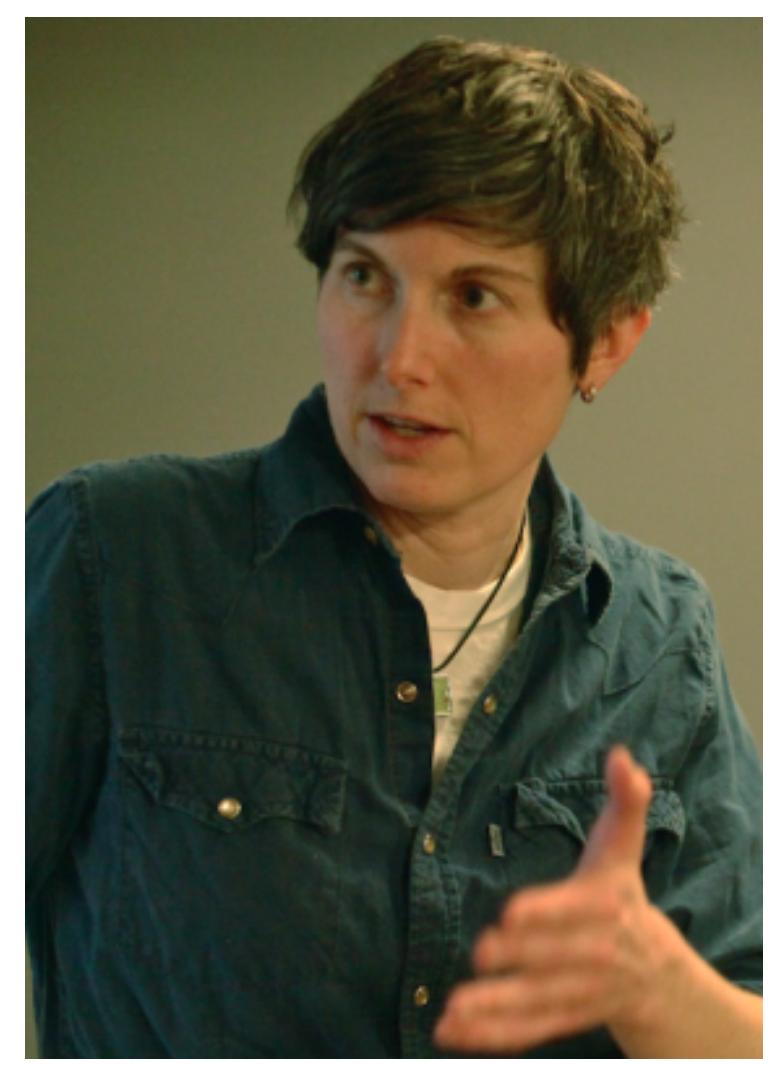

\section{Courtney Hermann}

\section{Adviser}

Courtney is a Portland based filmmaker and professor at Portland State University. She produces branded media with Boxcar Assembly LLC. 